\title{
Phosphorus dynamics in a highly polluted urban drainage channel- shallow reservoir system in the Brazilian semiarid
}

\author{
GERMÁRIO M. ARAÚJO' ${ }^{1}$, IRAN E. LIMA NETO ${ }^{1}$ and HELENA BECKER ${ }^{2}$ \\ ${ }^{1}$ Departamento de Engenharia Hidráulica e Ambiental, Universidade Federal do Ceará/UFC, Av. \\ Humberto Monte, s/n, Campus do Pici, B1. 713, 60451-970 Fortaleza, CE. Brazil \\ ${ }^{2}$ Departamento de Química, Universidade Federal do Ceará/UFC, Campus do Pici, B1. 940, 60455-760 Fortaleza, CE, Brazil
}

Manuscript received on May 5, 2018; accepted for publication on October 1, 2018

\begin{abstract}
How to cite: ARAÚJO GM, LIMA NETO IE AND BECKER H. 2019. Phosphorus dynamics in a highly polluted urban drainage channel-shallow reservoir system in the Brazilian semiarid. An Acad Bras Cienc 91: e20180441. DOI. 10.1590/0001-3765201920180441.

Abstract: This paper investigates phosphorus dynamics in a highly polluted system composed of a drainage channel followed by a shallow reservoir in the city of Fortaleza, Brazilian semiarid. During the dry season, significant non-point source loads of total phosphorus originated from residences unconnected to sewers were identified along the channel, resulting in an increasing flow rate of untreated sewage towards the reservoir. During the rainy season, as a consequence of dilution, phosphorus concentrations decreased by about 5 -fold. The results also revealed that the reservoir was acting similarly to a waste stabilization pond, with phosphorus removal efficiency of about 33\%. Assuming one-dimensional flow for the channel and complete mixing for the reservoir, it was possible to adjust phosphorus decay coefficients of $\mathrm{k}_{\mathrm{c}}=2.2$ day $^{-1}$ and $k_{r}=22.8$ year $^{-1}$, respectively, which were higher than their corresponding values available in the literature. This was attributed mainly to the relatively high temperatures and shallow water depths. The results also revealed an inverse dependence of $\mathrm{k}_{\mathrm{c}}$ and $\mathrm{k}_{\mathrm{r}}$ on water and wind velocity, with potential thresholds of respectively 0.3 and $5.0 \mathrm{~m} / \mathrm{s}$ for resuspension of bed sediments and internal phosphorus loading.
\end{abstract}

Key words: diffuse pollution, eutrophication, nutrients, semiarid, urbanization, water quality modeling.

\section{INTRODUCTION}

Eutrophication of urban waters is a worldwide problem which is associated with high phosphorus (P) loadings (Ruley and Rusch 2004, Bedore et al. 2008, Nyenje et al. 2014, Hobbie et al. 2017). In Brazil, despite the use of separate systems for sanitary sewer and stormwater runoff, only $50 \%$ of residences are connected to a sanitary sewer system

Correspondence to: Iran Eduardo Lima Neto

E-mail: iran@deha.ufc.br

ORCid: https://orcid.org/0000-0001-8612-5848 and only $43 \%$ of the sewage is treated (SNIS National Information System on Sanitation 2015). As a consequence, several urban water bodies are already hypereutrophic and need urgent restoration (Pacheco and Lima Neto 2017).

Previous studies on P modeling in water bodies have been reported by many authors (Vollenweider 1968, Castagnino 1982, Brown and Barnwell 1987, Havis and Ostendorf 1989, Salas and Martino 1991, Ruley and Rusch 2004, Pelletier and Chapra 2005, Chao et al. 2006, Lewis et al. 2007, Bowes et al. 2008, Chapra et al. 2016). The one-dimensional 
$\mathrm{P}$ transport equation is normally used for rivers and streams (Brown and Barnwell 1987). On the other hand, most studies related to lakes applied or modified the classical zero-dimensional $\mathrm{P}$ balance model of Vollenweider (1968) for temperate regions, which has been adapted by Salas and Martino (1991) for tropical lakes. Comprehensive reviews of $\mathrm{P}$ models and more sophisticated water quality models including nutrient dynamics for both rivers and lakes can be found in Shen et al. (2002) and Chapra (2008). Nevertheless, understanding $\mathrm{P}$ dynamics in hot arid/semiarid regions is still a problem that needs to be tackled. Moreover, the literature is also scarce with respect to $\mathrm{P}$ modeling in urban catchments, especially when a few residences are connected to sewers.

The main objective of this paper was to contribute to the understanding of $\mathrm{P}$ dynamics in a highly polluted urban drainage channel-shallow reservoir system located in the city of Fortaleza, in the Brazilian semiarid. More specifically, the objectives were: (1) to quantify non-point source loads of $\mathrm{P}$ along the channel from residences unconnected to sewers, (2) to investigate the flow conditions and their impacts on P dynamics, and (3) to adjust $\mathrm{P}$ decay coefficients for both the channel and the reservoir, and compare the results with those available in the literature for non-semiarid regions.

\section{MATERIALS AND METHODS}

\section{STUDY AREA}

The study was performed in an urban drainage channel-shallow reservoir system in Fortaleza, Ceará, Brazil, as shown schematically in Figure 1. Ceará is one of the eight Brazilian States located within the drought polygon, a highly populated Brazilian semiarid region, where thousands of surface reservoirs have been constructed to store water in the rainy periods and compensate the deficits in the dry periods (see Lima Neto et al.
2011). Fortaleza is the capital city of Ceará. This touristic city has more than 2.6 million inhabitants and the highest population density among Brazilian capitals $\left(>8,400\right.$ people $\left./ \mathrm{km}^{2}\right)$. While some parts of the city present a Human Development Index (HDI) very high $(>0.9)$, other suburban areas have a very low index $(<0.2)$, which are characterized by the predominance of residences unconnected to the sanitary sewer system. The channel-lake system studied in this paper is located within one of these city areas with very low HDI.

Figure 2 sketches the urban drainage channelshallow reservoir system. The channel is $2.5 \mathrm{~km}$ long and presents a rectangular cross section in concrete with height of $1.5 \mathrm{~m}$ and width of 5 $\mathrm{m}$. Upstream the channel, there is a lake called Parangaba with maximum depth of about $5 \mathrm{~m}$ and capacity of about $1.0 \mathrm{hm}^{3}$. Both this lake and the channel are surrounded by residences unconnected to the sewer system, which contribute with nonpoint source loads from untreated sewage along the perimeter of these water bodies. The reservoir (Lake Santo Anastácio) is located downstream the channel. It has a maximum depth of about 4 $\mathrm{m}$ and capacity of approximately $0.3 \mathrm{hm}^{3}$ (Araújo and Lima Neto 2018). Even in the dry season, the reservoir is constantly full, as it receives continuously untreated sewage from the channel. The reservoir discharges the outflows through a rectangular weir $2 \mathrm{~m}$ wide to the Maranguapinho river, one of the two main natural drainage systems of the city of Fortaleza (see Fig. 1).

\section{FIELD STUDY AND DATA ANALYSIS}

The field surveys were conducted during the rainy and dry seasons of May 2013 - February 2014 to assess the variability of flow rates and water quality in the channel-reservoir system. A propeller anemometer (Omni Instruments) was used to measure water velocities at sections S1, S2, S3 and S4 (see Figs. 1 and 2). Hence, with the aim of a ruler, it was possible to obtain the water depth 


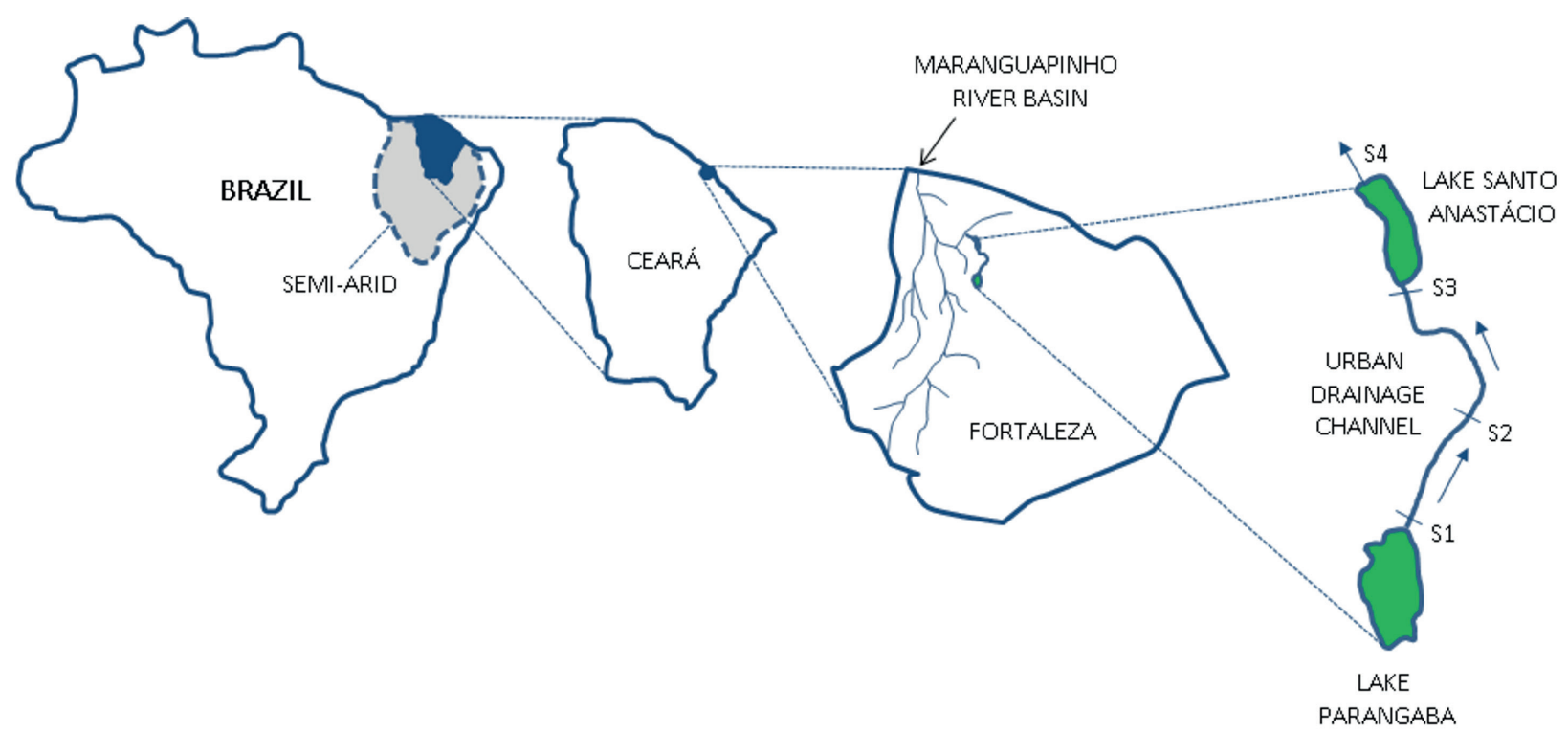

Figure 1 - Schematic of the urban drainage channel-shallow reservoir system located within the Maranguapinho River Basin, in the city of Fortaleza, Ceará State (Brazilian semiarid). Measurement sections S1 - S4 are also indicated.

URBAN DRAINAGE CHANNEL

LAKE SANTO ANASTÁCIO

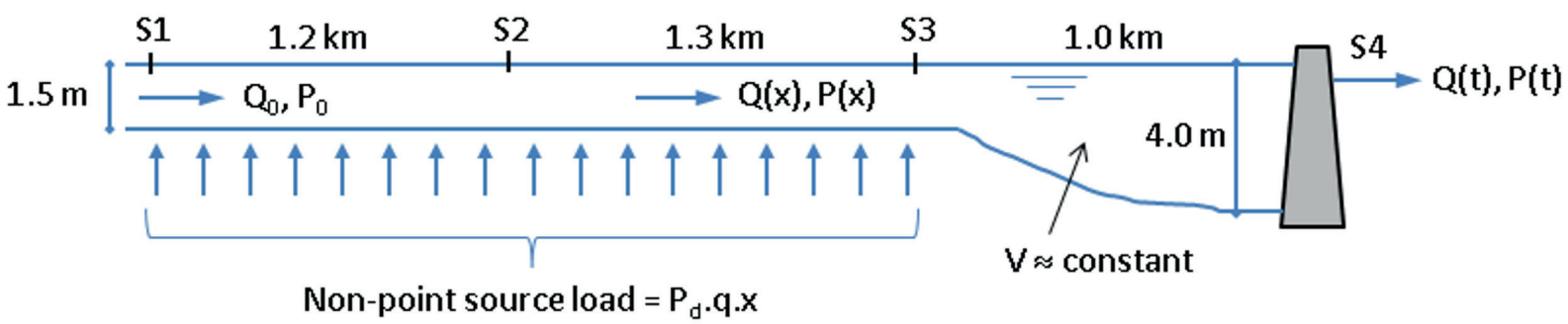

Figure 2 - Details of the urban drainage channel-shallow reservoir system. A distributed load of P from residences unconnected to the sewer system is also indicated.

and estimate the flow rate at each cross-section of the channel/reservoir for different flow conditions. Several culverts and illegal PVC pipes were also identified along the channel. The flow rates at some of these culverts/pipes were also measured with the aim of a bucket. Water samples were collected at each cross-section of the channel/reservoir and at some culverts/pipes using Van Dorn bottles in order to investigate the impact of non-point source loads from informal residences on $\mathrm{P}$ concentration along the channel/reservoir. The samples were analyzed for total phosphorus (P) in the Laboratório de Química Ambiental (LAQA) at the Universidade Federal do Ceará/ UFC, following the Standard
Methods (APHA 2005). Hydrological parameters including precipitation and wind velocity (at $10 \mathrm{~m}$ above ground) were also measured in a meteorological station located near the reservoir.

\section{MATHEMATICAL MODELING}

A general $\mathrm{P}$ balance equation can be written as following:

$\frac{\partial P}{\partial t}+\frac{\partial u P}{\partial x}+\frac{\partial v P}{\partial y}+\frac{\partial w P}{\partial z}=\frac{\partial}{\partial x}\left(\varepsilon_{x} \frac{\partial P}{\partial x}\right)+\frac{\partial}{\partial y}\left(\varepsilon_{y} \frac{\partial P}{\partial y}\right)+\frac{\partial}{\partial z}\left(\varepsilon_{z} \frac{\partial P}{\partial z}\right) \pm s \pm R(1)$

in which $\mathrm{P}$ is total phosphorus concentration, $\mathrm{t}$ is time, and $\mathrm{x}, \mathrm{y}$ and $\mathrm{z}$ are the longitudinal, transversal and vertical coordinates, respectively. In the LHS of 
Eq. (1), the first term refers to accumulation and the second-fourth terms refer to advection. In the RHS of Eq. (1), the first-third terms refer to dispersion, where $\varepsilon_{\mathrm{x}}, \varepsilon_{\mathrm{y}}$, and $\varepsilon_{\mathrm{z}}$ are the turbulent dispersion coefficients, while $\mathrm{S}$ and $\mathrm{R}$ are the external and internal sources $(+)$ or sinks $(-)$ of $\mathrm{P}$, respectively.

In the channel, assuming one-dimensional, steady-state and uniform flow in the $\mathrm{x}$ direction (see Fig. 2); neglecting the dispersion terms; and considering a linear increase in the flow rate given by $\mathrm{Q}=\mathrm{Q}_{0}+\mathrm{qx}$, where $\mathrm{q}$ is a constant rate of flow increase, Eq. (1) can be reduced to:

$\left(Q_{0}+q x\right) \frac{d P}{d x}=P_{d} q-P q-k_{c} A_{0} P$

in which $\mathrm{P}_{\mathrm{d}}$ is the total phosphorus concentration in the lateral flow (untreated sewage), $\mathrm{k}_{\mathrm{c}}$ is a coefficient of $\mathrm{P}$ decay in the channel due to algal uptake and settling, and $\mathrm{A}_{\mathrm{o}}$ is the area of the flow at the inlet. Thus, considering a constant velocity $\left(\mathrm{U}_{0}\right)$ along the channel, Chapra (2008) gave the following analytical solution to Eq. (2):

$P=\left[P_{0} e^{-k_{c} \frac{x}{U_{0}}}+\frac{P_{d} q\left(1-e^{-k_{c} \frac{x}{U_{0}}}\right)}{k_{c} A_{0}}\right] \quad\left(\frac{U_{0}}{U_{0}+q x / A_{0}}\right)$

In the reservoir, assuming complete mixing of the flow and a constant lake volume V (see Fig. 2), Eq. (1) can be reduced to:

$V \frac{d P}{d t}=W-Q P-k_{r} V P$

in which $\mathrm{W}$ and Q are the average phosphorus load and water inflow to the reservoir, respectively, and $\mathrm{k}_{\mathrm{r}}$ is a coefficient of $\mathrm{P}$ decay in the reservoir due to algal uptake and settling. Chapra (2008) provided the following analytical solution to Eq. (4):

$P=P_{0} e^{-\left(\frac{Q}{V}+k_{r}\right) t}+\frac{W}{\left(Q+k_{r} V\right)}\left[1-e^{-\left(\frac{Q}{V}+k_{r}\right) t}\right]$

Finally, Eqs. (3) and (5) were adjusted to field data in order to fit the $\mathrm{P}$ decay coefficients $\mathrm{k}_{\mathrm{c}}$ and $\mathrm{k}_{\mathrm{r}}$ for different flow conditions. The fitted values were analyzed as a function of water and wind velocities and contrasted to the values reported in the literature for non-semiarid regions.

\section{RESULTS AND DISCUSSION}

Figure 3 shows the seasonal variation of monthly averaged flow rates and phosphorus concentrations measured at different cross-sections (S1 - S4) in the channel-reservoir system. Observe that the flow rates were calculated from measurements of water depth $(\sim 0.1-0.4 \mathrm{~m})$ and velocity $(\sim 0.1-$ $0.4 \mathrm{~m} / \mathrm{s}$ ), and that a sediment layer with thickness of approximately $0.3 \mathrm{~m}$ was also identified at the bottom of the channel. The results shown in Fig. 3a indicate much larger flow rates during rainy events, with maximum values of about $600-1,000$ L.s ${ }^{-1}$ occurring in June 2013. As a consequence of urban runoff in the catchment, there was a significant increase in the flow rate along the channel (S1 - S3), while evaporation losses across the lake surface area slightly reduced the flow rate at the reservoir outlet (S4). On the other hand, minimum flow rates of about $20-80$ L.s ${ }^{-1}$ occurred in November 2013. Note that a massive increase in the flow rate along the channel ( $\sim$ 4-fold) was also observed during the dry period, which is attributed to the untreated sewage flow contributions from residences unconnected to the sewers. On the other hand, $\mathrm{P}$ values shown in Fig. $3 \mathrm{~b}$ ranged from about 0.5 to $7.0 \mathrm{mg} . \mathrm{L}^{-1}$, which were much higher than the limits allowed for natural rivers and streams $(0.1$ $\left.\mathrm{mg} . \mathrm{L}^{-1}\right)$ and lakes $\left(0.03 \mathrm{mg} . \mathrm{L}^{-1}\right)$, according to the Resolução 357/05 (Ministério do Meio Ambiente and CONAMA 2005). As a result of dilution, $P$ concentrations in the rainy season (high flows) were roughly 5 -fold lower than those in the dry season (low flows). The same trend has been reported by Bowes et al. (2008) for similar ranges of flow rates and phosphorus concentrations in rivers. This 

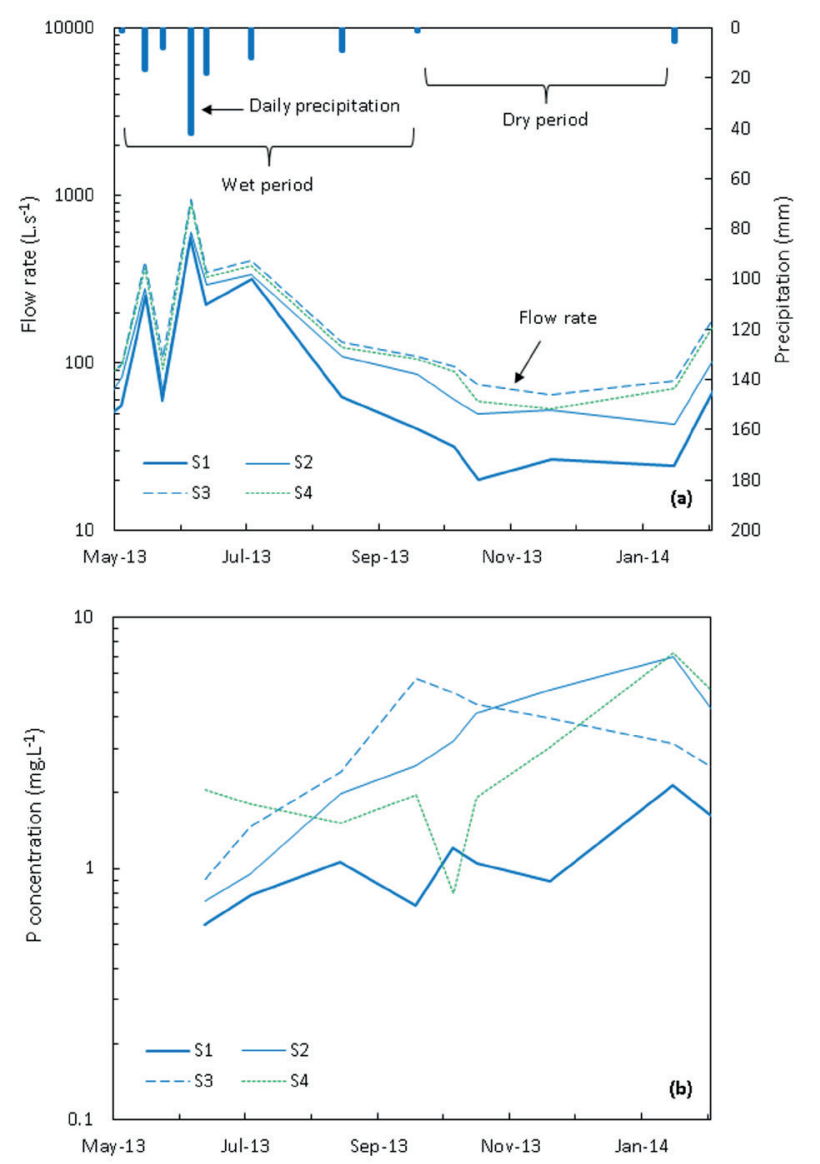

Figure 3 - Seasonal variation of (a) flow rate and (b) total phosphorus concentration measured at different cross-sections S1 - S4 along the channel-reservoir system.

implies that non-sewage diffused loads of $\mathrm{P}$ from the studied catchment were not relevant.

Figure 4 depicts box-plots of $\mathrm{P}$ concentrations measured at different locations, including the four cross-sections $\mathrm{S} 1$ - $\mathrm{S} 4$ and a culvert located between $\mathrm{S} 1$ and $\mathrm{S} 2$. The mean $\mathrm{P}$ concentration increased along the channel from about 1 to $3 \mathrm{mg} . \mathrm{L}^{-1}$, which is attributed to the dominant effect of lateral sewage inputs over the effects of uptake/settling. Note that typical $\mathrm{P}$ concentrations at the culverts were about $6 \mathrm{mg} . \mathrm{L}^{-1}$, which are within the ranges reported by Chapra (2008) for untreated domestic sewage. On the other hand, mean $\mathrm{P}$ concentration decreased through the reservoir from about 3 to $2 \mathrm{mg} . \mathrm{L}^{-1}$, resulting in a removal efficiency of about $33 \%$, similarly to waste stabilization ponds (see Von
Sperling 2007). However, it is interesting to stress that mean $\mathrm{P}$ concentration presented a progressive increase when comparing S1 to S4, which might result in serious water quality impacts downstream in the Maranguapinho River Basin (see Fig. 1).

Typical hourly variations of flow rates measured during the dry period at different crosssections and culverts are shown in Fig. 5. The data confirms that in the absence of precipitation, the increase in the flow rate along the channel was indeed because of the lateral sewage flow from informal residences. Note that about 20 culverts of $30-50 \mathrm{~cm}$ in diameter and more than 200 small pipes of $5-10 \mathrm{~cm}$ were identified over the $2.5 \mathrm{~km}$ reach of the channel. Figure 5 also suggests that during the dry season the flow rates were approximately constant, consistently with the results presented in Fig. 3a.

Figure 6 shows the rates of flow increase along the urban drainage channel as a function of daily precipitation. The results indicate a direct relationship between these two variables and the following correlation was adjusted with coefficient of determination $\mathrm{R}^{2}=0.5169$ :

$q=20.366 e^{0.0599 . \text { Precipitation }}$

Thus, when the daily precipitation is nil, Eq. (6) yields a value of $\mathrm{q}=20 \mathrm{~L} \cdot \mathrm{s}^{-1} \cdot \mathrm{km}^{-1}$. It is interesting to point out that this value is about 20 times larger than the maximum storm water infiltration rate of $1.0 \mathrm{~L} \cdot \mathrm{s}^{-1} \cdot \mathrm{km}^{-1}$ recommended by the Norma Técnica - NBR 9649 (ABNT 1986). On the other hand, when the daily precipitation is of the order of $40 \mathrm{~mm}$, Eq. (6) gives a much larger value of $\left.\mathrm{q}=2001 \cdot \mathrm{s}^{-1} \cdot \mathrm{km}^{-1}\right)$. Data available in Araújo (2016) provides a number of 42,036 inhabitants in the drainage area of the studied channel as well as a sewage contribution per capita of about $136 \mathrm{~L} /$ day. Thus, neglecting the small coverage of sewer systems in this area, we obtain $\mathrm{q}=26 \mathrm{~L} \cdot \mathrm{s}^{-1} \cdot \mathrm{km}^{-1}$, which is close to the above-mentioned value of 


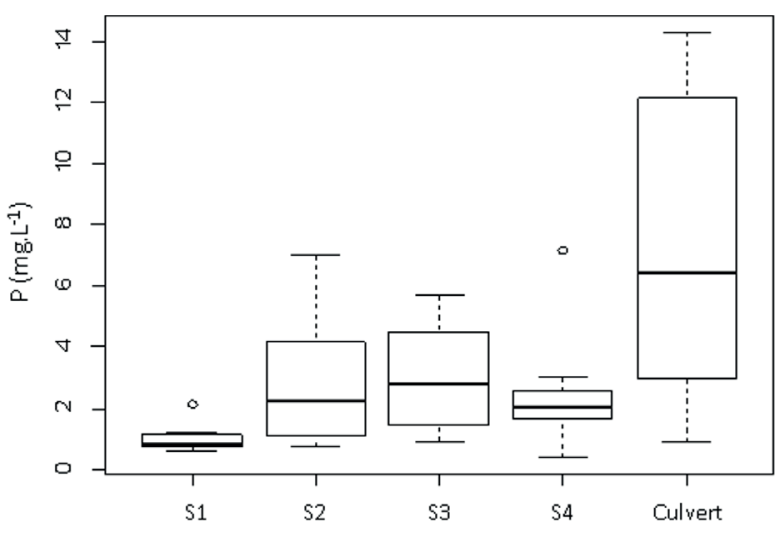

Figure 4 - P concentrations obtained at different locations, including the four cross-sections $\mathrm{S} 1-\mathrm{S} 4$ and a culvert located between $\mathrm{S} 1$ and $\mathrm{S} 2$.

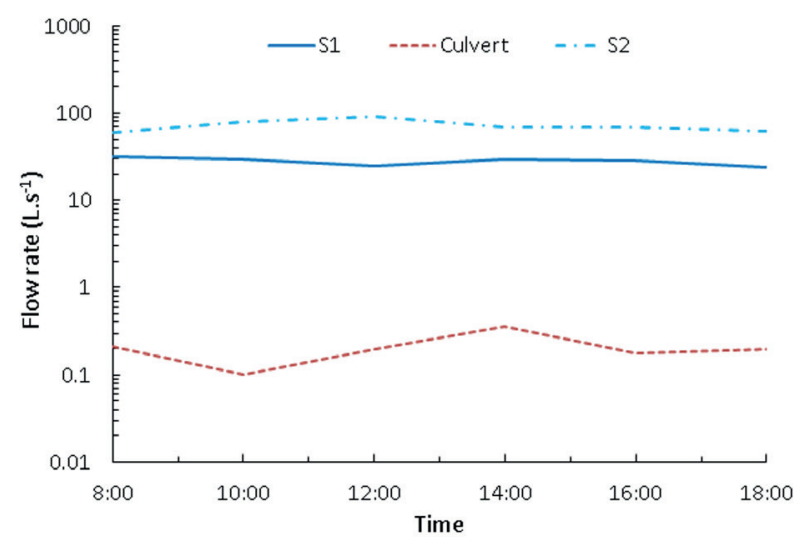

Figure 5 - Hourly variation of flow rates measured in November 14, 2013 (dry season) at S1 and S2, and at a culvert between these two cross-sections.

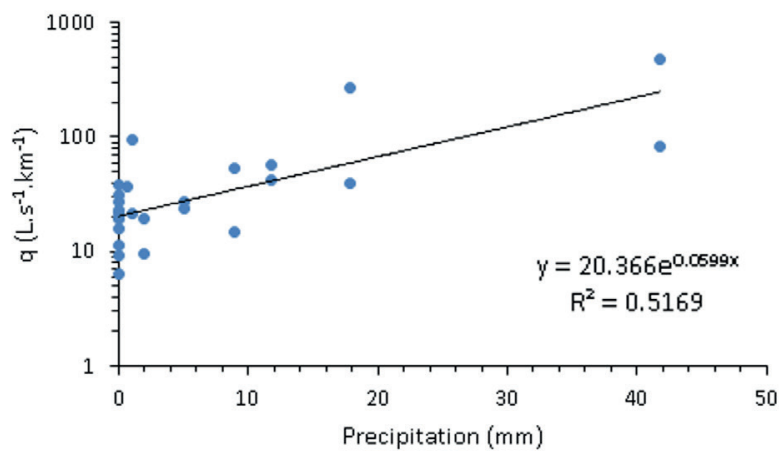

Figure 6 - Rates of flow increase obtained along the channel as a function of daily precipitation. about $20 \mathrm{~L} . \mathrm{s}^{-1} \cdot \mathrm{km}^{-1}$ observed along the channel during the dry period. This corroborates the idea that most of the lateral inflow to the channel comes from untreated domestic sewage discharges from residences unconnected to the sewers.

Figure 7 shows the total phosphorus decay coefficients fitted for the channel $\left(\mathrm{k}_{\mathrm{c}}\right)$ and reservoir $\left(\mathrm{k}_{\mathrm{r}}\right)$, which were obtained respectively by adjusting Eqs. (3) and (5) to field data for different flow conditions. Error bars represent standard deviations obtained when more than two data points were available. The results show an inverse dependence of these coefficients on water and wind velocity, indicating clear thresholds of about 0.3 and $5.0 \mathrm{~m} / \mathrm{s}$, respectively, after which these coefficients became negative, suggesting the possible domination of resuspension of bed sediments and internal $\mathrm{P}$ loading over degradation of $\mathrm{P}$ due to uptake/settling, as pointed out by Søndergaard et al. (2003) and Welch and Cooke (2005) for shallow lakes. Note that the above-mentioned values are close to the limits of $0.2 \mathrm{~m} / \mathrm{s}$ (water velocity) and $6.0 \mathrm{~m} / \mathrm{s}$ (wind velocity) reported by Bengtsson and Hellstrom (1992) and Madsen et al. (2001) for resuspension of bed sediments in streams and shallow lakes, respectively. Nevertheless, the average values of $\mathrm{k}_{\mathrm{c}}\left(=2.2\right.$ day $\left.^{-1}\right)$ and $\mathrm{k}_{\mathrm{r}}\left(=22.8\right.$ year $\left.^{-1}\right)$ were positive. For rivers and streams, Chapra (2008) reported a maximum value of $\mathrm{k}_{\mathrm{c}}=0.8 \mathrm{day}^{-1}$. Correcting this value to the present water temperature $\left(\sim 28^{\circ} \mathrm{C}\right), \mathrm{k}_{\mathrm{c}}$ becomes about 1.8 day $^{-1}$, which is close to the value obtained here $\left(\mathrm{k}_{\mathrm{c}}\right.$ $=2.2$ day $^{-1}$ ). Two possible reasons for the high value of $\mathrm{k}_{\mathrm{c}}$ adjusted in this study are the relatively low water depths and the high concentrations of organic matter, which may increase the settling rates, as $k_{c}$ is a function of $\mathrm{v} / \mathrm{H}$, where $\mathrm{H}$ is the water depth and $\mathrm{v}$ is the apparent settling velocity which is expected to increase with particle size (see García 2008). On the other hand, the value of $\mathrm{k}_{\mathrm{r}}$ adjusted here is about 4.1 and 2.0 times higher than those obtained by using the correlations of Vollenweider (1968) and Salas and Martino (1991) for temperate and tropical lakes, 

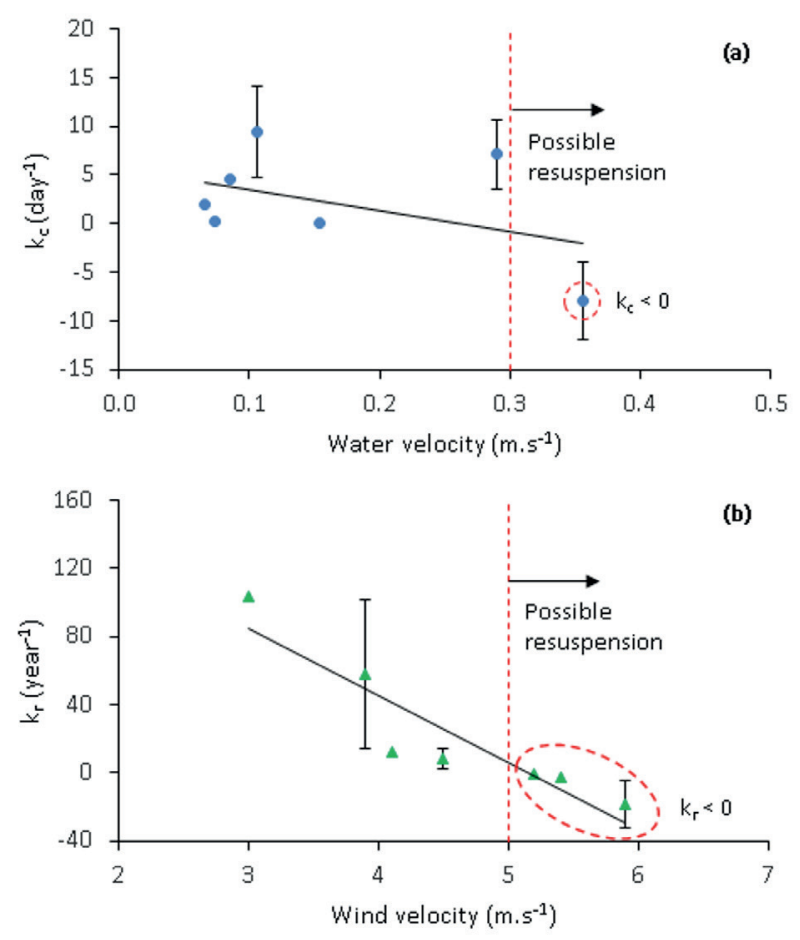

Figure 7 - Inverse dependence of $\mathrm{P}$ decay coefficient on water and wind velocities obtained for (a) the channel and (b) the reservoir, respectively, indicating potential thresholds (dashed lines) for resuspension of bed sediments/internal P loading. Solid lines are curves fitted to the data and error bars represent standard deviations.

respectively. Note that the temperature correction procedure of Castagnino (1982) yields a value of $\mathrm{k}_{\mathrm{r}}$ of about 28 year $^{-1}$, which is close to the adjusted value $\left(\mathrm{k}_{\mathrm{r}}=22.8\right.$ year $\left.^{-1}\right)$ for the present hot semiarid reservoir.

\section{CONCLUSIONS}

Field studies performed in a highly polluted urban drainage channel-shallow reservoir system in the Brazilian semiarid revealed significant non-point source loads of total phosphorus from residences unconnected to the sewer system. As a consequence of dilution, phosphorus concentrations decreased by about 5 -fold during the rainy season but were still much larger than the limits allowed by the CONAMA 357/05. Average phosphorus removal efficiency in the reservoir was $33 \%$, which suggests that it was functioning similarly to a waste stabilization pond. Adjusting a one-dimensional model for the channel and a complete mixing model for the reservoir to the field data, it was possible to fit phosphorus decay coefficients of $\mathrm{k}_{\mathrm{c}}=2.2$ day $^{-1}$ and $\mathrm{k}_{\mathrm{r}}=22.8$ year $^{-1}$, respectively, which were higher than the values in the literature, possibly because of the relatively high temperatures and shallow water depths in the present study. The results also indicated that $\mathrm{k}_{\mathrm{c}}$ and $\mathrm{k}_{\mathrm{r}}$ are inversely dependent on water and wind velocities, with potential thresholds of 0.3 and $5.0 \mathrm{~m} / \mathrm{s}$ for resuspension of bed sediments and internal phosphorus loading, respectively.

\section{ACKNOWLEDGMENTS}

The authors appreciate the financial support from the Conselho Nacional de Desenvolvimento Científico e Tecnológico (CNPq) and the Fundação Cearense de Apoio ao Desenvolvimento Científico e Tecnológico (FUNCAP) (Project \# PNE-011200042.01.00/16).

\section{AUTHOR CONTRIBUTIONS}

Germário M. Araújo conducted the field and laboratory studies, analyzed the data, and drafted the manuscript. Iran E. Lima Neto helped to draft the field and laboratory planning, analyzed the data, performed the mathematical modeling, and contributed to the manuscript. Helena Becker helped to conduct laboratory studies, processed the experimental data, and gave critical feedback to the manuscript. All authors have approved the final article.

\section{REFERENCES}

ABNT - ASSOCIAÇÃO BRASILEIRA DE NORMAS TÉCNICAS. 1986. National Guidelines for Sewer System Design, NBR 9649 (in Portuguese).

APHA - AMERICAN PUBLIC HEALTH ASSOCIATION. 2005. Standard Methods for the Examination of Water and Wastewater, $21^{\text {st }}$ ed., Washington, D.C.

ARAÚJO GM. 2016. Analysis and integrated modelling of water quality in an urban drainage channel-eutrophic 
reservoir system in Fortaleza/CE. PhD Thesis, Universidade Federal do Ceará /UFC (in Portuguese).

ARAÚJO GM AND LIMA NETO IE. 2018. Removal of organic matter in stormwater ponds: a plug-flow model generalisation from waste stabilisation ponds to shallow rivers. Urban Water J 15(9): 918-924.

BEDORE P, DAVID M AND STUCKI J. 2008. Mechanisms of Phosphorus Control in Urban Streams Receiving Sewage Effluent, Water Air Soil Pollut 191: 217-229.

BENGTSSON LAND HELLSTROM T. 1992. Wind-induced resuspension in a small shallow lake. Hydrobiologia 241: $163-172$

BOWES MJ, SMITH JT, JARVIE HP AND NEAL C. 2008. Modelling of phosphorus inputs to rivers from diffuse and point sources. SCI Total Environ 395: 125-138.

BROWN LC AND BARNWELL TO. 1987. The enhanced stream water quality models QUAL2E and QUAL2E-UNCAS: documentation and user manual. US Environmental Protection Agency. Office of Research and Development. Environmental Research Laboratory.

CASTAGNINO WA. 1982. Investigación de modelos simplificados de eutroficación en lagos tropicales. Organizacion Panamericana de la Salud. Centro Panamericano de Ingenieria Sanitaria y Ciencias del Ambiente. Versión Revisada (in Spanish).

CHAO X, JIA Y, COOPER CM, SHIELDS JR FD AND WANG SSY. 2006. Development and Application of a Phosphorus Model for a Shallow Oxbow Lake. J Environ Eng 132: 1498-1507.

CHAPRA SC. 2008. Surface Water-Quality Modeling. Waveland Press.

CHAPRA SC, DOLAN DM AND DOVE A. 2016. Massbalance modeling framework for simulating and managing long-term water quality for the lower Great Lakes. J Great Lakes Res 42(6): 1166-1173.

CONSELHO NACIONAL DO MEIO AMBIENTE (2005). "Dispõe sobre a classificação dos corpos de água e diretrizes ambientais para o seu enquadramento, bem como estabelece as condições e padrões de lançamento de efluentes, e dá outras providências.” Diário Oficial da República Federativa do Brasil, Brasília, Brasil (in Portuguese).

GARCÍA MH (Ed). 2008. Sedimentation Engineering: Processes, Measurements, Modeling, and Practice. Reston, VA: American Society of Civil Engineers, ASCE Manual of Practice 110.

HAVIS RN AND OSTENDORF DW. 1989. Approximate dynamic lake phosphorus budget models. J Environ Eng 115: 809-821.

HOBBIE SE, FINLAY JC, JANKE BD, NIDZGORSKI DA, MILLET DB AND BAKER LA. 2017. Contrasting nitrogen and phosphorus budgets in urban watersheds and implications for managing urban water pollution. PNAS 114(16): 4177-4182.

LEWIS GN, AUER MT, XIANG X AND PENN MR. 2007. Modeling phosphorus flux in the sediments of Onondaga Lake: Insights on the timing of lake response and recovery. Ecol Model 209: 121-135.

LIMA NETO IE, WIEGAND MC AND ARAÚJO JC. 2011. Sediment redistribution due to a dense reservoir network in a large semiarid Brazilian basin. Hydrolog Sci J 56: 319-333.

MADSEN JD, CHAMBERS PA, JAMES WF, KOCH EW AND WESTLAKE DF. 2001. The interaction between water movement, sediment dynamics and submersed macrophytes. Hydrobiologia 444: 71-84.

SNIS - NATIONAL INFORMATION SYSTEM ON SANITATION. 2015. http://www.snis.gov.br (in Portuguese).

NYENJE PM, MEIJER LMG, FOPPEN JW, KULABAKO R AND UHLENBROOK S. 2014. Phosphorus transport and retention in a channel draining an urban, tropical catchment with informal settlements. Hydrol Earth Syst Sci 18: 1009-1025.

PACHECO CHA AND LIMA NETO IE. 2017. Effect of Artificial Circulation on the Removal Kinetics of Cyanobacteria in a Hypereutrophic Shallow Lake J Environ Eng 143(12): 06017010, p 1-8.

PELLETIER GJ AND CHAPRA SC. 2005. QUAL2Kw theory and documentation (version 5.1), A Modeling Framework for Simulating River and Stream Water Quality.

RULEY JE AND RUSCH KA. 2004. Development of a simplified phosphorus management model for a shallow, subtropical, urban hypereutrophic lake. Ecol Eng 22: 7798.

SALAS HJ AND MARTINO P. 1991. A simplified phosphorus trophic state model for warm-water tropical lakes. Water Res 25(3): 341-350.

SHEN HH, CHENG AHD, WANG KH, TENG MH AND LIU CCK. 2002. Environmental Fluid Mechanics: Theories and Applications. ASCE.

SØNDERGAARD M, JENSEN JP AND JEPPESEN E. 2003. Role of sediment and internal loading of phosphorus in shallow lakes. Hydrobiologia 506-509: 135-145.

VOLLENWEIDER RA. 1968. Scientific fundamentals of the eutrophication of lakes and flowing waters with particular reference to phosphorus as factors in eutrophication. Tech. Rept. DAS/C81/68, Organ Econ Coop Dev, Paris, France.

VON SPERLING M. 2007. Waste Stabilisation Ponds: Biological Wastewater Treatment. Volume 3. IWA.

WELCH EB AND COOKE GD. 2005. Internal phosphorus loading in shallow lakes: importance and control. Lake Reserv Manage 21: 209-217. 